\title{
Sharing the Burden of the Border: Layered Security Co-operation and the Canada-US Frontier
}

\author{
StÉFANIE VON HLATKY Queen's University \\ JESSICA N. TRISKO University of Western Ontario
}

\section{Introduction}

At 5,525 miles, or 8,891 kilometres, the Canada-United States border has typically been praised as the longest undefended border in the world. Ninety per cent of Canada's population lives within 100 miles of this border. Economically speaking, the border is vital to Canada with the two countries sharing one of the largest trade relationships in the world, valued at $\$ 1.8$ billion $^{1}$ in daily cross-border trade. Since the attacks of September 11, 2001, border management has been a constant concern for both Canadian and American policy makers and major stakeholders as security concerns have increased at the border with significant implications for the flow of both goods and people. These concerns are well reflected in US Homeland Security Secretary Janet Napolitano's state-

\footnotetext{
Acknowledgments: The authors are grateful for the support offered by the McGillUniversité de Montréal Centre for International Peace and Security Studies (CIPSS, formerly the Research Group in International Security), the Security and Defence Forum (SDF) at the Department of National Defence, the Fonds québécois de recherche sur la société et la culture (FQRSC), the Social Science and Humanities Research Council of Canada (SSHRC) and the Canada Institute at Woodrow Wilson International Center for Scholars. A previous version of this article was presented at the Woodrow Wilson International Center for Scholars and the 2009 ISSS/ISAC conference. We thank the three anonymous CJPS reviewers for their insights. All errors remain our own.
}

Stéfanie von Hlatky, Department of Political Studies, Queen's University, Room C321, Mackintosh-Corry Hall, 99 University Avenue, Kingston, Ontario K7L 3N6, stefanie. vonhlatky@mail.mcgill.ca

Jessica N. Trisko, Department of Political Science, University of Western Ontario, Social Science Centre, Room 4154, London, Ontario N6A 5C2, jessica.trisko@mail. mcgill.ca 
ment that "we're no longer going to have this fiction that there's no longer a border between Canada and the United States" (CBC News, 2009b).

North American border policy has undergone a process of adaptation in response to these new security imperatives. With regards to both economic and security co-operation, the Canada-US relationship is asymmetric by all material indicators of power. Security co-operation at the border is nevertheless the product of bilateral negotiations and arrangements in the pursuit of common goals. While the Canada-US relationship was premised on, and has evolved as, a partnership built on "formal equality, consensus building, and a great deal of informal contact," a great deal of tension remains in issue areas such as border policy (Mason, 2005: 386). Border management is also layered in that it requires the participation of actors from all levels of government within both countries.

This article examines patterns of asymmetric security co-operation between Canada and the United States to assess how Canada has managed changes in border policy since $9 / 11$. We pay special attention to the role of Quebec which, in the realm of border security, has furthered Canadian interests vis-à-vis the United States, due to its well-organized political network in neighbouring states, as well as in Washington DC. Drawing on the insight of Clarkson (2001), as well as Gattinger and Hale (2010), that Canadian national policy making has become simultaneously internationalized and localized, we seek to answer the following questions. Is Canada disadvantaged when dealing with the United States on this sensitive topic? How do sub-national actors within Canada, such as the province of Quebec, contribute to national border policy? We argue that the actions of Quebec have enhanced Canada's position vis-à-vis the United States because of a clear alignment in the policy objectives of these two actors. Quebec is thus seen as a major player in Canadian strategies of asymmetric security co-operation with the United States.

Quebec and Canada's role in security co-operation with the United States can be understood in the context of burden-sharing explanations of transnational policy co-ordination, which have traditionally focused on the ability of the weaker party in institutional arrangements to gain a free ride. That is, the stronger party is assumed to bear a larger share of the costs as the leader of the arrangement while the weaker party benefits from the positive externalities generated by the actions of the stronger party. However, the extent to which this argument applies across issue areas in the security realm is unclear. We take issue with the free-rider view of border security management between the United States and Canada and propose an alternative approach focused on the differentiated concerns held by contiguous states.

Despite the asymmetry in material power between these two countries, we argue that the underlying distribution of capabilities cannot predict which partner will drive the agenda on a particular issue. ${ }^{2}$ The extent 
Abstract. Effectively managing the Canada-US border has emerged as a major security challenge post-9/11. Burden-sharing theories suggest that the United States would take the lead on border security due to its hegemonic role in ensuring North American security, while smaller nations such as Canada enjoy a free ride. We refute the free-rider hypothesis and propose an approach which accounts for the differentiated concerns held by contiguous states. By dedicating sizeable resources to the issue of border security and by appealing to advantageous negotiation strategies, Ottawa has leveraged its position as a secondary state vis-à-vis the United States. Efforts employed by the province of Quebec have bolstered Canada's relative influence in this issue area. We argue that Quebec and Ottawa perceived and acted on complementary interests which empowered the Canadian government to respond more forcefully to US-driven border security measures after $9 / 11$. We conclude with alternative models to border security management, as well the practical implications of our argument.

Résumé. Un des défis majeurs depuis le 11 septembre 2001 concerne la gestion de la frontière entre le Canada et les États-Unis. Les théories sur le partage du fardeau supposent que les États-Unis sont l'acteur dominant dans l'élaboration des politiques frontalières, assurant la sécurité du continent nord-américain. En contrepartie, les états secondaires, comme le Canada, se voient souvent attribuer le rôle du passager clandestin dans ces interactions. Cet article porte sur le partage du fardeau entre le Canada et les États-Unis en ce qui a trait à la sécurité frontalière. Nous réfutons l'hypothèse du passager clandestin en proposant une approche qui prend compte des préoccupations distinctes des deux états voisins. En investissant d'importantes ressources pour la gestion de la frontière et en appliquant des stratégies de négociations avantageuses, Ottawa a su surmonter son statut de puissance moyenne face aux États-Unis. Le Québec a contribué au renforcement de la position canadienne en agissant de concert avec Ottawa, puisque les deux paliers poursuivaient des intérêts complémentaires. Le résultat de cette coopération est une riposte cohérente et soutenue démontrée par le gouvernement canadien face aux mesures de sécurité initiées par les États-Unis après le 11 septembre. Enfin, nous discutons également des implications pratiques de notre argument en comparant les différents modèles dans la litérature portant sur la gestion de la sécurité frontalière.

to which a state is willing to take the initiative and to devote time and resources to a task depends on how significant this task is to its national interests. One state may care more about an issue area than another state, regardless of size, and this often translates into different approaches to the problem at hand. Therefore, while Canada's attempts at policy independence may be interpreted by the United States as free riding (see Sands, 2008), we argue that burden-sharing arrangements for North American security are best seen as a division of labour, with the dominant partner making specific requests about what is expected on the part of the contributing partners.

Additionally, the contributions of secondary states like Canada should be judged according to operational needs and placed in their proper context rather than in absolute terms based on the size of those contributions alone. How secondary states respond to such requests in the realm of border security policy is an important theoretical and empirical puzzle. Secondary states, like Canada, can deploy strategies that can overcome the disadvantage inherent in asymmetric security co-operation. In this context, sub-national actors such as Quebec can play a key role due to the layered structure of border management. 
The Canadian and American views on border security policy are clearly different. Although both states care about their physical security, Canada is more sensitive to the economic repercussions of changes in border security policy and has taken unilateral steps to protect itself from the negative externalities of shared border management. Additionally, the decentralized nature of Canada's federal system led to opposition from important segments of society despite the relative absence of public debate over changes in Canada's security policy following $9 / 11 .^{3}$ Nevertheless, certain provinces have emerged as important actors supporting Canada's position on border security. Below, we argue that Quebec's actions are bolstering Canada's leverage over the United States when it comes to the negotiation and re-negotiation of North American border policy.

Taking $9 / 11$ as a point of departure, we examine the policy changes and adaptations that emerged in the new security context and assess the success of policy innovations in reconciling provincial and federal concerns. We find that both levels of government are pursuing complementary interests rather than acting at cross purposes. Indeed, this dynamic has enabled the Canadian government to respond more effectively to the new border management measures implemented by the United States after 9/11. In the next section, we introduce the relevant theoretical literature as a framework for our analysis of North American border security management. Following this, we discuss how 9/11 has shaped security concerns on both sides of the border and employ data from multiple Canadian and American government agencies to assess the impact of changes along the Canada-US border following 9/11. We then focus on Quebec to illustrate the regional dimension of border security and the importance of reconciling security imperatives which operate at the provincial and federal levels. In doing so, we show that Quebec's role can, in the case of border security, enhance Canada's position vis-à-vis the United States. Next, we provide an assessment of the future of Canada-US border security co-operation with reference to alternative security arrangements that have been proposed. In conclusion, we offer avenues for future research and discuss the practical implications of the article from a policy standpoint.

\section{Theoretical Perspectives on Burden-Sharing and Security Co-operation}

The conventional view regarding asymmetric co-operation has focused on the role of power differentials within existing alliance relationships. Realist authors offer rationalist predictions about burden-sharing between allies, arguing that security co-operation with allies is a function of costbenefit calculations (Miller, 1998). Concerns over relative gains are cited as the main impediment to co-operation (for example, Grieco, 1990; 
Snidal, 1991; Waltz, 1979), while gaps between the aggregate military capabilities of the actors dictate the form and direction of co-operation (Posen, 2006). Such arguments presuppose that the dominant power in the alliance will dictate the conditions of co-operation and highlight the tendency of the weaker partner to pursue reactive defensive policies, driven by its ties to the stronger state.

Several alternative theoretical frameworks have been applied to the case of Canada-US security co-operation. The liberal view of asymmetric security co-operation has focused in large part on shared values which mitigate the threat posed to liberal societies such as Canada by the overwhelming power of the United States (Owen 2001/2002). In addition to shared liberal values, states are able to overcome the impediments to co-operation arising from asymmetry because trade and economic integration are a source of peaceful relations among nations (Keohane and Nye, 2001). An open international economy has a moderating influence on conflict between states because it creates bonds of mutual interest and a commitment to the status quo (Gilpin, 1987: 31). However, whether co-operation between Canada and the United States is seen as arising from their strong trade relationship or a shared philosophical viewpoint, the liberal view neglects the fact that economics and security are often competing interests.

Constructivist and other ideational approaches have framed Canada-US security co-operation in terms of a North American security community. The existence of such a community, characterized by the peaceful resolution of disputes and the absence of the threat of conflict, is seen as the foundation for efforts toward economic and security integration between the two countries (see Adler and Barnett, 1998; Andreas and Biersteker, 2003; Bukowczyk et al., 2005; Haglund, 2010; for an alternative view, see Gonzalez and Haggard, 1998). Within this community, the United States is often depicted as playing a hegemonic role in establishing North American security norms and practices. Despite this attention to asymmetry, constructivist perspectives have failed to capture the diversity of interests within North American societies and minimized instances where Canadian and American interests are at odds.

While the United States is clearly the dominant partner in this particular security relationship, we believe that Canada can deploy autonomyenhancing strategies when negotiating and co-operating with the United States. For example, the layered architecture of border policy has enabled Quebec to partner with the Canadian government to leverage the United States, a point which will be addressed later. Although the United States takes on a disproportionate share of the costs when engaging in security co-operation with its allies, focusing on this alone obscures the valued contributions of secondary states, making every ally look like a freerider. To have a more balanced and operationalisable concept of burden- 
sharing, we must analyse how American and Canadian expectations about security are negotiated. We thus employ a more nuanced account of asymmetric security co-operation by focusing on the interests which drive Canada-US interactions in the realm of border security.

In the context of a long-standing security relationship, such as that between Canada and the United States, we can assume that a minimal consensus about security goals has emerged over time. Indeed, the more enduring the alliance, the more likely it is that partners will want to invest in upgrading the alliance rather than terminating it (Hirschman, 1970). Moreover, in the Canada-US case, co-operative arrangements are supported by a hegemonic power willing to bear a greater share of the burden (Walt, 1997). This case is particularly relevant to what Zartman (1997) terms the "structuralist paradox"- that situations of asymmetry can in fact produce better agreements than symmetric negotiations - or as Zartman and Rubin put it, "that the most powerful party in terms of force or resources does not always win at negotiation" (Zartman and Rubin, 2002: 12). By rejecting realist definitions of power as force and instead focusing on persuasion, influence, leverage and pressure, Zartman (1997: 18) contends that weaker powers can compensate for their weakness through several strategies, such as appealing to principle or building coalitions on particular issues.

The durability of asymmetric alliances, such as that between Canada and the United States, is due in large part to complementary interests between the partners and the ability of the weaker party to make its demands and expectations heard. The way such views translate into policy and public opinion is articulated by Meyers who states there exists

a perception by Americans that Canadians think security and border issues are only a US problem and that Canadians are not taking seriously enough the security issues. In this view, Canadians are taking action only to humour the Americans and to achieve their other goals, particularly maintenance of a good relationship with the United States and complete and open access to the border, both crucial to their economy... Canadians, on the other hand, admittedly focused on their economy and the facilitation of people and goods, question whether the United States isn't overly focused on security to the exclusion of all other items, including economics and common sense. This issue becomes increasingly complicated as it relates to perceptions of sovereignty, identity, and independence. (2003: 15)

While Canada and the United States are clearly engaged in an asymmetric relationship, Canada can choose to assert its sovereignty by bearing the burden of its portion of the collective responsibility. As Sands notes, "where Canada chooses not to 'free ride' on the military contributions of others, it can make a significant contribution to its own national security and that of its allies" (2008: 106). 
In this context, it is essential to ask whether Canada is simply a freerider caught up in American security interests or whether Canada is pursuing its own interests within the context of a bilateral relationship. Free-rider theory holds that the stronger alliance partner bears the brunt of the costs, while the weaker party is able to free ride, enjoying the benefits of the alliance without adequately contributing to the costs (Olson, 1971). An alternative hypothesis is that burdens are shared according to the benefits respectively received by the allies (Sandler, 1993). Given substantial power differentials, weaker allies can minimize the appearance of free riding through certain concessions, such as agreeing to the foreign use of military bases, making minimal troop commitments to joint missions or substituting participation with other forms of contribution such as increased foreign aid (for example, Donnely and Serchuk, 2005; Katada, 1997; Sakurada, 1998).

We find that these perspectives regarding free riding fail to adequately describe Canada's role in border security management. Canada does not simply undertake symbolic actions to minimize potential criticism from the United States. Neither does Canada shirk its responsibilities at the border. Rather, Canada-US co-operation regarding border security is best explained in terms of an ongoing process of interest harmonization and a growing recognition that economic and security concerns at the border are two sides of the same coin. Thus, we find our perspective to be closer to Zartman than either the traditional liberal or realist views of asymmetric co-operation. The following section focuses on 9/11 as a catalyst for change in North American border security policy and its effect on shared interests regarding the Canada-US border. In a later section, we turn to Quebec's contribution to Canadian border security objectives and strategies as an illustration of how Canadian concerns are being voiced.

\section{9/11 and the Border Security Shock}

Seen as the first major attack on the American homeland since the 1941 bombing of Pearl Harbor, 9/11 had a profound effect on the nation's psyche and challenged prevailing definitions of security. The events of 9/11 had a lasting impact on American threat perceptions and both domestic and international security policy (Bowman, 2005). As a result, priorities on both sides of the border shifted. The official discourse in the United States regarding border policy came to strongly prioritize security concerns over economic ones. The fact that Canada and the United States shared an undefended border became a liability for the United States, rather than the asset it once was. On the Canadian side, the new priority became reassuring the United States about border security with- 
out impeding trade. These changing priorities brought about a major reorientation in North American border security co-operation.

American policy toward its northern neighbour has been hard to label in the post 9/11 period. While Secretary Napolitano has attempted to communicate the Obama administration's nuanced approach to border management, stating, "Let's not pretend that we can just wave a magic wand and we have a shared border management structure. It's not an easy thing to accomplish" (2009: 7), what is often referred to as the "thickening of the border" has involved the introduction of measures which make border management more cumbersome and slow down cross-border movement. These measures, detailed below, include an increase in the number of border guards, the introduction of new technology to enhance border security and changing travel requirements for transit between Canada and the United States. The term "thickening" refers to these increased security measures and the resulting congestion which impede cross-border flows. The term has been repeatedly used by Prime Minister Harper in joint press conferences with Presidents Bush and Obama to express Canadian concerns about American border management policies (CBC, 2008; Mayeda, 2009). Controversy over this term reflects that fact that the American view of the implications of changes in border policy differs from the Canadian one as evidenced by Secretary Napolitano's statement that "I think that phrase 'thickening of the border'... I found it a difficult phrase. I'm not sure it's an accurate characterization" (Savage, 2009). Regardless of these semantic disagreements, the increasing importance of the northern border in American security policy reflects the fact that, as Pastor argues, "US national security depends more on co-operative neighbours and secure borders than it does on defeating militias in Basra" (2008: 84).

The concern over the thickening of the border stems from the fact that Canada had largely been sheltered from more intrusive security measures until the 9/11 Commission report recommended that security along the Canadian and Mexican borders be tightened. This has been identified by some as the point at which US border interests became hegemonic in North America. As Lennox suggests, "in defining terrorism as the primary existential threat to the North American homeland, the United States established a new security paradigm to which the Canadian state has no option but to conform. In practice this means duplicating in Canada the reconfiguration of the American state that was carried off after 9/11" (2007: 1021). This has resulted in what we term the application of the homeland security paradigm in Canada.

The creation of the Department of Homeland Security (DHS) immediately after 9/11 reflected a strong trend toward centralization on the American side. Canada followed suit with the creation of its Department of Public Safety in 2003. Now known as Public Safety Canada, this depart- 
ment was intended to serve the same co-ordination functions as DHS through the Government Operations Centre (GOC) which brings together an array of public safety and security-related government organizations, including the RCMP, Health Canada and the Canadian Security Intelligence Service (Public Safety Canada, 2009). The GOC is responsible for maintaining contact with the United States and NATO as well as Canadian provinces and territories which feature their own security organizations. Another example of Canada's willingness to conform to American expectations is Canada's 2009 Intelligence Reform and Terrorism Prevention Act which imposes stricter measures for border crossing in response to American recommendations. However, the responsiveness of Canada to American demands for increased security measures even prior to the 9/11 Commission report has been clearly demonstrated and is based on the mutuality of interdependence among the two countries in protecting their domestic populations (Sands, 2008).

Post-9/11 American national security concerns were addressed partly through measures such as the Smart Border Action Plan (Public Safety Canada, 2008). Developed after the December 12, 2001 signing of the Smart Border Declaration, the goal of the action plan is to build stronger border co-operation between Canada and the United States and to improve the flow of people and goods through stronger infrastructure and more efficient information sharing between the two countries (Foreign Affairs and International Trade Canada, 2001). The smart border is conceptualized as an intelligence-based strategy which keeps terrorists and other criminal activity out while letting the flow of commerce in. Bilateral agreements such as the action plan paved the way for the expansion of Canada-US co-operation under the North American Security and Prosperity Partnership (SPP) to include American security arrangements with Mexico. Although this initiative has been abandoned, the SPP was a promising dual-bilateral strategy to remove obstacles to trade and facilitate the flow of people and cargo, to improve emergency response and critical infrastructure protection and to implement common border security strategies. The SPP was meant to work in the direction of harmonizing border policies, placing Canada on equal footing with Mexico in terms of addressing security concerns on the US borders (see Andreas, 2005; Clarkson, 2008; Golob, 2008; Healy and Katz, 2008; Sokolsky and Lagassé, 2006).

The SPP aside, the adoption of the smart border approach is seen as an uncharacteristic demonstration of the United States' willingness to re-conceptualize its approach to its physical borders and as an acknowledgement that it cannot attain additional security through unilateral actions alone (Meyers, 2003). By engaging Canada in creating a smart border, the United States has demonstrated that it does not have an overriding position in border management. The participation of secondary states is essential in ensuring the security of the dominant partner, but in practice, Canada 
and Mexico vary in their ability to do so. Canada-US security co-operation under the smart border approach has involved the enhancement of integrated border enforcement teams (IBETs) as a joint effort to increase the responsiveness of enforcement agencies on both sides of the border that had traditionally worked individually. IBETs have grown to include the Royal Canadian Mounted Police (RCMP), the Canada Border Services Agency (CBSA), the US Customs and Border Protection/Office of Border Patrol (CBP/OBP), the US Bureau of Immigration and Customs Enforcement (ICE) and the US Coast Guard. Three IBETs currently operate along the Quebec frontier with New York, Vermont and Maine.

Canada's seemingly tacit acceptance of the American approach to homeland security and its emulation of certain policy changes within the United States does not mean that the application of this paradigm to Canada occurred without due consideration of the particular challenges that Canada faces. Harvey (2007), in particular, stresses the potentially pernicious effects of what he terms the "homeland security dilemma" whereby the more security a nation has, the more it will need as enormous investments made in security inevitably raise public expectations and amplify public outrage after subsequent security failures. While Canada has been responsive to key American demands, particularly in the fields of intelligence sharing and terrorism prevention, Canadian border security policy has not been simply dictated by the United States. The emergence of a shared border management structure has been the outcome of a process of negotiation on both sides of the border. Canada has been engaged by the United States as a key partner and has undertaken substantial unilateral initiatives of its own in which certain provinces have played a critical role, as we discuss below with the case of Quebec.

In addition to engaging Canadian agencies in co-operative arrangements, the United States has undertaken some unilateral initiatives which reflect its dominant position in North America. One of the most important initiatives for Canadian border security has been the more than sixfold increase in northern US border agents since 9/11. This includes the 2009 move to dispatch an additional 700 agents to patrol the CanadaUnited States border, bringing the total number of American border officers along the northern border to approximately 2,200 by September 2010 (MacLeod, 2009). These changes reflect in part the growing preoccupation with the Canada-United States border by Secretary Napolitano, who has stressed the legal non-differentiation between the United States' northern and southern borders and who incorrectly suggested during a 2009 interview that "to the extent that terrorists have come into our country or suspected or known terrorists have entered our country across a border, it's been across the Canadian border" (CBC News, 2009b).

For its part, Canada has taken substantial unilateral initiatives in strengthening the border. These actions have shown the willingness of 
Canada to invest in national security independent of American demands. Since 9/11, approximately $\$ 4$ billion worth of infrastructure projects have been undertaken on the Canadian side of the border (Transport Canada, 2009). A key policy change has been the arming of Canada's border guards. Prompted by several walk-outs by border officers faced with dangerous incidents (see CBC News, 2006), Prime Minister Harper's government promised $\$ 101$ million to hire 400 additional CBSA officers in order to eliminate work-alone situations and to pay for weapons training. The program aims to arm 4,800 officers at all ports of entry, as well as officers who perform enforcement functions within Canada (CBSA, 2009). This initiative helps bring the capabilities of Canada's border guards in line with those of their American counterparts, but has not been accepted without criticism. The Akwesasne First Nations community has been in the forefront of opposition to this policy (see Barrera, 2009a, 2009b; Chiefs of Ontario, 2009). The arming of Canada's border guards is a clear attempt by Canada to overcome an existing asymmetry at the border without prompting or support from the United States.

To summarize, the process of border security enhancement initiated by the United States post-9/11 has had far-reaching implications for North American security co-operation. Canada has engaged the United States constructively to address these mutual security concerns and to reassure America about its commitment to the new security measures. In so doing, Canada has been mindful of the economic repercussions of such measures, a concern echoed by several provinces, including Québec, as well as American states along the northern border.

\section{The Economic Repercussions of Policy Change}

Canada is more economically dependent on the United States, making its stake in the border management debate much greater. The post-9/11 North American trade environment has its roots in the Canada-US Free Trade Agreement of 1987 (which entered into force in 1989) and the North American Free Trade Agreement (NAFTA) of 1994, which permitted Canada to lock in what had been negotiated bilaterally in 1987 (Golob, 2008: 85). To reap the benefits of free trade, Canada and the United States adopted the Shared Border Accord in 1995 which created a long-term investment plan to improve infrastructure and harmonize regulation procedures in order to create one of the most efficient borders in the world.

The aftermath of 9/11 shifted the American objective from ensuring efficient trade to creating a secure border, resulting in "a challenge that threatens the very success of future North American free trade" (Bradbury and Turbeville, 2008). Canadian statements during this period reflected the fact that "economic security defined the national interest, 
making market access via the border the sine qua non of national survival" (Golob, 2008: 87). However, Canada has increasingly come to recognize that economic and security interests are two sides of the same coin. As Public Safety Minister Toews recently noted, "We have to satisfy the Americans that we are also concerned about security and that we are a reliable partner because if we don't, that will impact our economic well-being. If we can't do that, it will result in a thickening of the border between the United States and Canada" (De Souza, 2010).

Despite new American security measures which affect Canada directly by imposing greater controls over the circulation of goods across the border, including the Container Security Initiative, the Customs-Trade Partnership against Terrorism, and the Free and Secure Trade program (FAST), Canada has sought to implement security measures in a way which minimizes negative effects on trade. Much emphasis has been placed on establishing FAST and NEXUS ${ }^{4}$ border crossings and devoting considerable resources to infrastructural improvements at crossings vital to commerce. Nevertheless, the degree to which the Canadian economy is linked to the speed of cross-border travel remains an important concern for policy makers and citizens alike, particularly since delays at ports-of-entry have persisted despite ongoing improvements.

The current global economic downturn has also put pressure on crossborder trade between Canada and the United States. Exports to the United States are, as for the rest of Canada, vital to Quebec's economy, representing 80 per cent of its international exports and worth approximately $\$ 57$ billion (MRI, 2006a: 13). However, no clear consensus has emerged regarding the impact of new border regulations on Canada-US trade at the national or provincial levels. As indicated in Figure 1, Canadian merchandise trade with the United States has remained fairly stable in the post-9/11 period. Yet, at the very least, new security regulations have increased the costs of shipping goods to the United States. In the United States, frustrations have been felt at the state level with business groups speaking out about the economic losses incurred due to the slowdown at the border. Shifting patterns in the use of specific border crossings greatly impact on border communities (CBC News, 2009a), with some suggesting that American security measures are equivalent to non-tariff trade barriers between Canada and the United States (MacPherson and McConnell, 2007: 301; see also Andreas, 2003; Andreas and Biersteker, 2003; Bradbury and Turbeville, 2008).

One side effect of the increased costs of doing business post-9/11 has been the effort by some Canadian businesses to move away from the US market (MacPherson et al., 2006). More recent studies suggest that there have been significant adverse effects on Canadian exports. For example, Globerman and Storer $(2008,2009)$ suggest that public and private sector programs put in place since 9/11 may not as yet have compen- 
FIGURE 1

Annual Canadian Merchandise Trade with the United States, 2000-2009

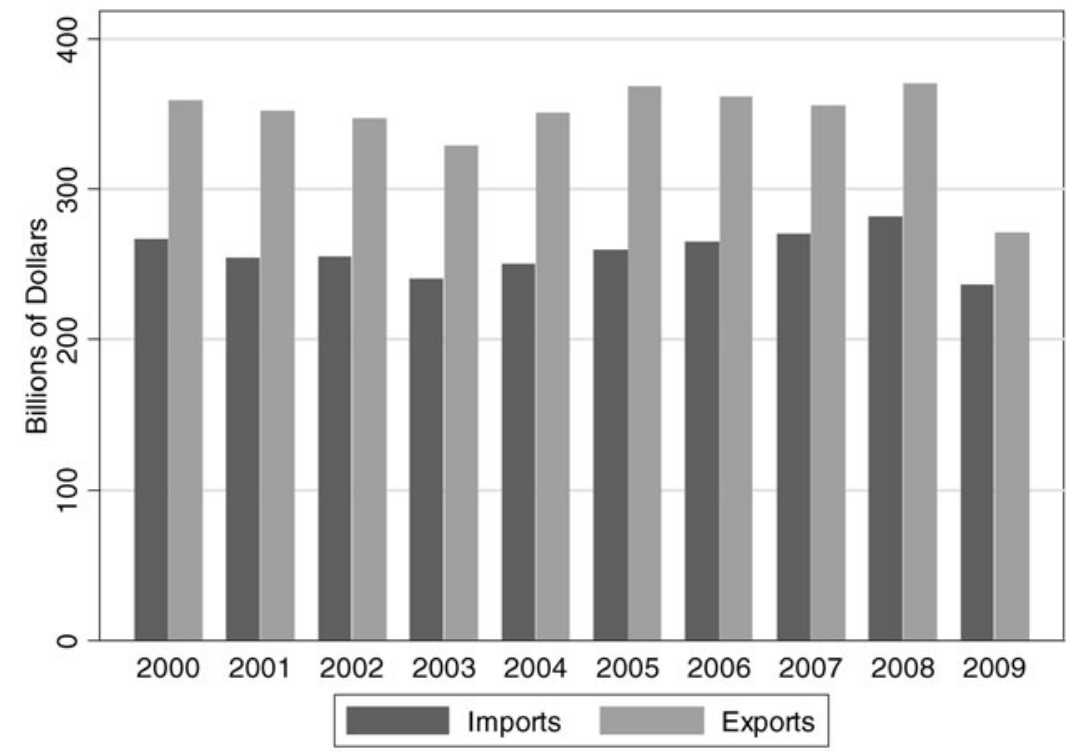

Source: Statistics Canada (2011a).

sated for the additional costs imposed by new border security regulations. Others question why two countries which are party to a free trade agreement even continue to have customs officers stationed at the border (Meyers, 2003: 15).

In focusing primarily on the economic repercussions of $9 / 11$, Canadian policy makers did not fully appreciate the challenges that the country's federal structure would pose in formulating and executing a new approach to border management. The following section employs a case study of Quebec to illustrate how recent developments have forced a reconsideration of Canada's commitment to the smart border approach and the American homeland security paradigm. Below, we argue that Quebec's stand on border security has enhanced Canada's position visà-vis the United States.

\section{Changes along the Quebec-US Frontier}

Quebec's role in Canadian border security reflects important regional variations in border management. As a province within the federation 
of Canada, Quebec operates under the "Gérin-Lajoie doctrine" (see Paquin, 2006; also McRoberts, 2001). This doctrine implies that Quebec ensures, at the international level, the extension of its domestic areas of constitutional jurisdiction and enables Quebec to sign non-binding international agreements with sovereign countries. Based on its application of the Gérin-Lajoie doctrine, Quebec's international security objectives as defined by the Quebec Department of International Relations or Ministère des Relations internationales (MRI) to include preserving the flow of trade, making strategic infrastructure more secure and ensuring that Quebec does not become a source of threats to its partners (MRI, 2006b: 23). Quebec's interests, so defined, are aligned with the interests pursued by the Canadian government.

Moreover, Quebec can deploy resources to bolster Canada's position when engaging with the United States. Quebec's international presence is based on its Delegations and General Delegations, the mandate of which includes establishing lasting relationships with governments, opinion leaders and policy stakeholders and using their position of influence to expand Quebec's market and expertise (MRI, 2010). Quebec's relationships with American states and strong presence in Washington serve to extend Canada's reach when Quebec and Ottawa share the same goals. Canada thus benefits from a multi-level network that is an asset in bilateral negotiations and an asset which is unmatched on the American side. ${ }^{5}$ This layered approach to security co-operation has worked to redress the asymmetry inherent in the Canada-US relationship. Indeed, Canada's position has been strengthened by Quebec's emphasis on transnational threats and decentralized policy implementation.

The Quebec government has been a strong proponent of the decentralized approach to border management, claiming that today's security threats are best addressed at the provincial level rather than the federal level. Though there is a strong organizational interest in perceiving border management as decentralized, the so-called "new" threats to security, such as transnational organized crime, terrorism and threats to public safety and health, all require a solution that does not necessarily involve the military or other exclusively federal jurisdictions. In its various policy statements, the MRI lays out a list of threats which preoccupy international organizations, national governments and local governments alike and describes how government agencies at all levels share jurisdictions over these problems. The federal government has recognized this new dynamic in its National Counter-Terrorism Plan.

The government of Quebec gives special emphasis to reconciling provincial interests with federal policy requirements and has taken unilateral steps in response to post-9/11 security imperatives. A key initiative has been the conclusion of bilateral agreements with bordering states including Vermont, Maine, Massachusetts, New Hampshire and New York. 
Nevertheless, local governments in both Quebec and the United States have expressed dissatisfaction with the continued centralization of national security policy since $9 / 11$. The tension that sub-national governments face in responding to national challenges is expressly highlighted by Thacher (2005) who stresses that the costs of security are borne by locals while the benefits of enhanced national or international security are not easily measured in terms of local gains. Although measures to prevent terrorism have focused primarily on border security, provincial level policy changes have also played an important role, including collaboration with the United States to ensure the security of critical infrastructure (De Souza, 2010), as well as public information technology systems and personal information which may be used by potential terrorists.

With regard to border security, the government of Quebec, through the Sûreté du Québec (SQ) and the City of Montreal Police Department (SPVM), implements Canadian and American federal initiatives (MRI, 2008). An important provincial program designed to ensure increased border security while giving greater liberty to the province's population has been the enhanced driver's license (EDL), developed by the Société de l'assurance automobile du Québec (SAAQ). Costing approximately $\$ 12.8$ million to implement, the EDL may be used in place of a passport by travellers entering the US by land or sea. ${ }^{6}$ For the program to break even, about 10 per cent of drivers in Quebec, or a total of 500,000 people, must request an EDL and pay the additional \$40 fee (Dougherty, 2009). The continued ease of travel between Canada and the United States at Quebec border crossings will ultimately determine the future success or failure of this provincial program. ${ }^{7}$

Other Quebec initiatives include the creation of the Internal Security Branch and Information Security Management Centre, the creation of SQ's counter-terrorism department, the permanent assignment of the SQ to the Maritime Security Enforcement Team and the securing of infrastructure at Hydro-Québec's publicly owned power generation facilities (MRI, 2008; MRI, 2010). The government of Quebec actively participates in the Northeast Regional Homeland Security Directors Consortium which is comprised of ten states and the provinces of Ontario and New Brunswick. Through its Ministère des Transports, Quebec belongs to several multilateral alliances such as the Eastern Border Transportation Coalition (EBTC) which encompasses states and provinces along the eastern segment of the Canada-US border (MRI, 2006a: 14). The development of these organizational relationships has served to enhance rather than restrict the autonomy of Quebec as a political actor (see Kukucha, 2008).

When examining the effects of new border security policies in the province of Quebec, it is clear from Figure 2 that traffic from Quebec into the United States, though variable, has remained stable or declined 
FIGURE 2

United States Border Crossings from the Quebec Region by Car and Bus, 2000-2009

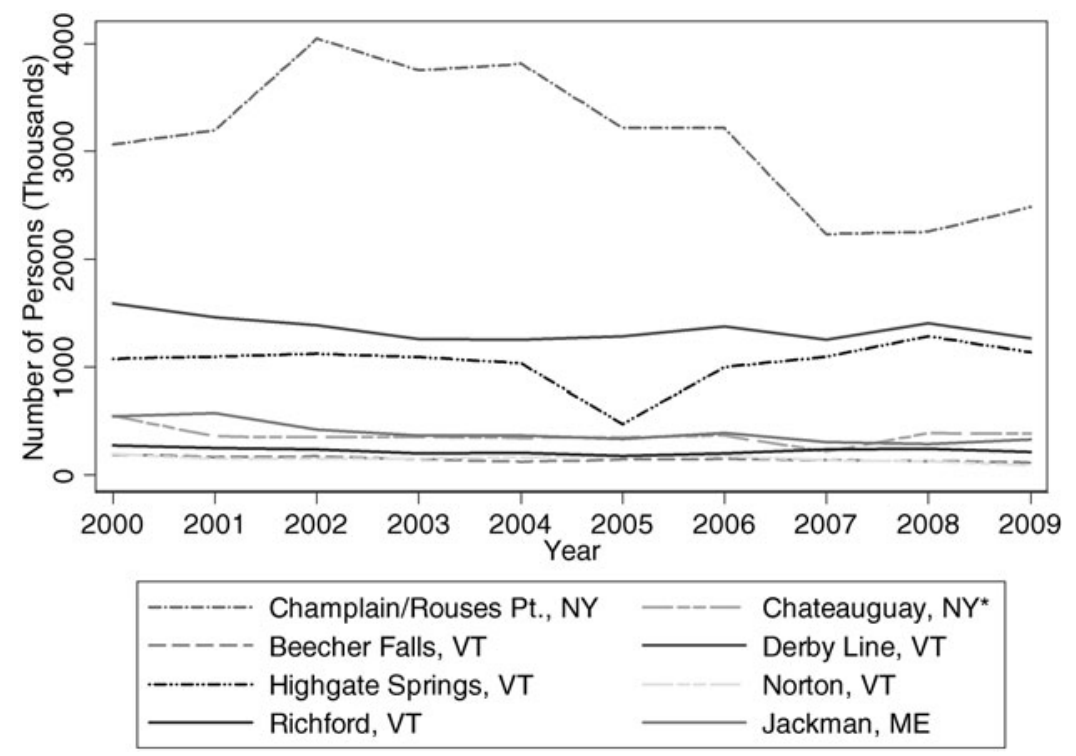

Source: U.S. Department of Transportation (2011).

at almost every significant border crossing in the region since 2002 . Despite efforts made by the Quebec government subsequent to the Smart Border Declaration, participation in the new security programs by Quebec businesses remains a strategic challenge. Until now, few of Quebec's small and middle-sized businesses have registered for the smart border transit programs with the risk that over the medium term this will negatively affect the competitiveness of Quebec businesses that export to the US market (MRI, 2006a: 15). Similarly, the low enrolment rates of trucking firms in FAST have been pointed to as an ongoing concern (Globerman and Storer, 2009: 184).

Even so, cross-border travel in Quebec offers a different picture from the national one. Given the continued travel by Canadians to the United States as illustrated in Figure 3 below and the notable decrease in American travel across the Canada-US border since 2001, a clear asymmetry in the importance of the border continues to exist. While cross-border travel and tourism is a complex issue, the perception by American officials and policy makers of the ease with which the Canadian border can be crossed does not seem to match the reality of American northbound 
FIGURE 3

Canada-United States Cross-Border Travelers, 2000-2009

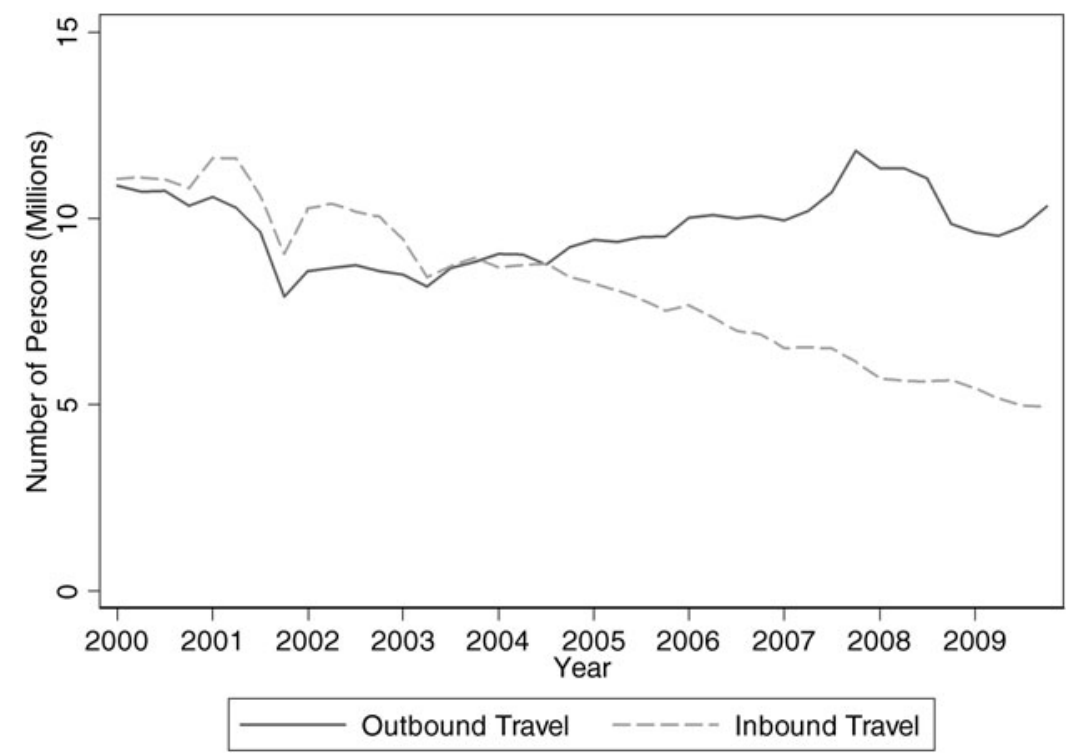

Source: Statistics Canada (2011b).

travel. However, the seemingly increasing difficulty of crossing the Quebec frontier into the United States suggests that changes are taking place at the border with important repercussions for the economic growth of the region.

In spite of the existing challenges, both the American and Canadian publics appear to support deepening security co-operation at the border. Public opinion surveys (SES and the University at Buffalo, 2007) show that Americans and Canadians favour closer co-operation with each other on border security issues. 67.2 per cent of Quebec respondents were in favour of deeper border security co-operation with the United States while 76 per cent of northeastern respondents favour closer co-operation with Canada. In terms of national security, 70 per cent of Quebec respondents and 84.7 per cent of northeastern respondents believed that existing co-operation between Canada and the United States should be maintained or increased.

The case of Quebec demonstrates that it is possible to reconcile provincial and national security concerns. Although decisions relating to border issues fall under the exclusive jurisdiction of the federal government, these decisions have a direct impact on the responsibilities of the prov- 
inces which must adjust their legislation, policies and programs accordingly. The provinces are not invited to bilateral negotiating tables, yet their participation is essential to the successful implementation of the smart border approach. It is in this context that the layered framework of border management has created a space for Quebec to further Canadian interests. Quebec's actions are bolstering Canadian efforts in the realm of border security by cultivating strong ties with American states and through its sustained presence in Washington, as exemplified by the Quebec Government Office. Not only is Canada taking independent initiatives regarding border security, but so are its sub-national governments, which are uniquely positioned to design tailored, local responses to national policy objectives. Burden sharing along the Quebec-US frontier is therefore taken up in large part by agencies from the province of Quebec such as the SQ.

Quebec also demonstrates the importance of identifying the actors involved in executing shared border management strategies. Multiple actors are often at work with competing interests. This is reflected in part by Quebec's continued assertion that transnational security threats require local responses and that critical infrastructure should be protected by local agencies. In the case of border security, Quebec has instrumentalized the layered security architecture to further the Canadian position, a show of support which may not be forthcoming in other distinct issue areas.

\section{The Future of Canada-US Border Security Co-operation}

Alternatives to the smart border approach have failed to gain much momentum in policy-making circles despite their prominence in the Canadian foreign policy literature. One option is the external perimeter strategy which emphasizes border security at the external boundaries of Canada and the United States while reducing the emphasis on the internal Canada-US border, where levels of interaction and commerce make it more difficult to provide effective security. As MacPherson and colleagues argue, "In essence, the goal would be to develop a bordermanagement philosophy similar to the one adopted by the European Union" (2006: 317). Like the EU, in moving toward an external perimeter strategy, Canada should seek to build a larger sense of a North American community which would serve to secure its political sovereignty while protecting the Canadian economic interest by creating enforceable rights and obligations (Gotlieb, 2004: 39). This view is clearly aligned with Prime Minster Harper's perspective that Canada is a country of the Americas and that "Re-engagement in our hemisphere is a critical international priority for our Government. Canada is committed 
to playing a bigger role in the Americas and to doing so for the long term" (Harper, 2007). Proposed institutions for the external perimeter strategy include a customs union, a North American commission and a common team of customs and border guards to man the borders and the continental perimeter.

A modest step in this direction was taken when President Obama and Prime Minister Harper signed a perimeter security deal on February 4, 2011. The Beyond the Border initiative introduces a number of measures such as jointly operated border facilities, a harmonized entryexit system for travellers in Canada and the United States and greater information sharing. The goal is to target threats before they reach North America, thereby enabling both countries to ease traffic at their shared border in order to facilitate trade. Even with the December 2011 action plans, there is currently no set budget for the implementation of this agreement, making it difficult to estimate how different Beyond the Border will be from the Smart Border Accords.

Prior to the signing of the Obama-Harper deal, the perimeter approach was perceived as dangerous in Ottawa, representing an expansion of Canada's security obligations beyond what the country was perhaps able to perform. In fact, the rejection of an EU-like structure which would entail the reduction of national sovereignty for participating governments is enshrined in the previously dominant smart border approach (SPP, 2009). While this can be attributed to an explicit attempt to sideline domestic opposition to border management changes in Canada (Healy and Katz, 2008), national sovereignty concerns and a reluctance on the part of the American government to cede risk-management responsibilities to its counterparts (Globerman and Storer, 2009: 184), a commitment to advancing Canada's privileged position vis-à-vis Mexico (Golob, 2008: 84) or simply the fact that bilateral negotiations have proven to be a successful strategy in the past (Meyers, 2003: 25), the dual decentralized bilateral approach contributed to differentiation in the importance of the Canada-US border in each country's national security policies.

Other proposed alternatives involve the development of a Canada-US customs union (see Dobson, 2002; Goldfarb, 2003). Bilateral external tariff harmonization, in the context of a customs union, would free up resources for firms to meet existing smart border security procedures (Globerman and Storer, 2009). Complying with existing NAFTA regulations is seen as a similar alternative while the development of a common market is seen as an option offering even deeper integration within North America. However, by focusing solely on the economic repercussions of new border regulations these proposals may overlook the broader security implications of further Canada-US integration. Such proposals are also largely agnostic on the role of Mexico or Latin American countries 
in further integration efforts despite the Harper government's steps towards greater engagement in the Americas.

Regardless of what alternatives are considered, it has become increasingly clear that the Obama administration should move towards a continental approach to border security. Given past efforts, such as NAFTA, which aimed to eliminate the borders between the three countries, it seems counterproductive for the Obama administration to raise new walls. The dual-bilateral strategy of the SPP exacerbated the defining and debilitating characteristic of the United States' relations with its neighbours - asymmetry - and failed as a policy (Pastor, 2008). A North American approach, as advocated by Pastor (2008), should be premised on the belief that each country benefits from its neighbours' successes and each is diminished by their problems or setbacks. Overcoming the asymmetries that exist in North America is the long-term key to ensuring security on the continent. While the thickening of the Canada-US border has spurred greater co-operation between the two nations, it has not led either country to be safer in a measurable way and has had clear negative effects on trade and the day-to-day lives of those in border communities.

\section{Conclusion}

A number of lessons can be drawn when considering the evolution of North American border policy since 9/11. First, we need to look beyond the actions of central governments to gain a complete picture of the policy-making process, even in areas of exclusive federal jurisdiction. We have mentioned that, when engaging with the United States on a bilateral level, Canadian politicians and bureaucrats can gain from taking the initiative to ensure successful policy outcomes. Sometimes, however, there are important political constraints operating in Washington or Ottawa, which curtail progress on Canada-US collaboration. In 2011, both President Obama and Prime Minister Harper suffered important political setbacks. Obama had to deal with a very defiant Congress and threats of a government shutdown. On the Canadian side, Harper's minority government suffered the ultimate challenge of a no-confidence vote loss (156 to 145) resulting in the call for a May 2011 election, nearly three months after the perimeter security deal. When central governments are so constrained, it is important to consider the actions of subnational actors. This can be seen across issue areas as exemplified by regional climate change initiatives in the United States and Canada, such as the Western Climate Initiative. On the border management front, the previous decade was characterized by significant activism from Canadian provinces and bordering American states. We think that such exam- 
ples of sub-national diplomacy deserve more attention in the literature on North American co-operation.

A second important lesson relates to the decentralization of border policy, where provinces are taking on a greater role in the implementation of border management and influencing policy outcomes in the process by adapting central policies to local conditions. Quebec has been vocal about opting for a more decentralized approach when it comes to border management, citing the diffuse nature of today's new security threats, threats which provinces and local governments may be better equipped to respond to than the federal government.

Third, despite growing sub-national activism and decentralization in border policy, the relationship between the provincial and federal levels of government can be productive when their interests are aligned. In the realm of border security, we have shown that both the province of Quebec and Ottawa were pursuing similar objectives following the post-9/11 security measures: reassuring Americans about Canada's ability to protect its territory from outside threats, while finding ways to do so that would not impede trade. In this sense, Quebec's outreach activities in the United States reinforced the Canadian position and the scope of its diplomacy.

Finally, despite the costs imposed by the smart border approach, a number of benefits can be identified. As a result of this approach, Quebec is emerging as an important actor in North American border security. Its bilateral treaties with various American states testify to the fact that many border security issues cannot be addressed solely at the federal level. In addition, the smart border approach has brought increased co-operation at the organizational level between federal, provincial and local agencies, and between Canadian agencies and their American counterparts. The integration of various security-related organizations may lead to better and more comprehensive security provisions on both sides of the border in the future.

In sum, there remains room for improvement in Canada-US border management. The leaders of Canada and the United States, as well as Mexico, need to articulate a clear vision for North American security that moves away from the current focus on land borders and adequately deals with the transnational issues-including public health threats, the drug trade and climate change-which may become the most relevant threats to national security in the future. For now, there is the Beyond the Border agreement, which remains a strictly bilateral endeavour. In light of this, future research should be directed towards assessing whether a process of collective securitization of transnational issues is occurring on the North American continent (see Haacke and Williams, 2008). As border security policy moves beyond the internal Canada-US border towards a perimeter-based approach, our understanding of the future security environment must also move forward. 


\section{Notes}

1 All figures are reported in Canadian dollars unless specified to be otherwise.

2 Our argument, like that of Bow (2009), challenges thoroughly structuralist accounts of the Canada-US relationship which emphasize the overriding role of power asymmetries. We support his view regarding the potential for Canada to pursue an autonomous foreign policy yet we stress the role of critical provinces in shaping or bolstering Ottawa's negotiating power.

3 The United States has experienced similar state-level mobilization on border policy.

4 NEXUS is designed to expedite the border clearance process for low-risk, preapproved travellers into Canada and the United States. Eligible individuals apply for acceptance into the program which is geared towards frequent cross-border travellers. For more details, see the CBSA's NEXUS page at http://www.cbsa-asfc.gc.ca/ prog/nexus/menu-eng.html (April 12, 2011).

5 The idea of a multi-level network is inspired from the literature on European integration and multi-level governance. See, for example, Marks and colleagues (1996) and Jachtenfuchs and Kohler-Koch (2004).

6 Enhanced driver's licenses are available in the provinces of British Columbia, Ontario and Quebec. Enhanced identity cards are available in the provinces of British Columbia and Manitoba. See the Canadian Border Services Agency's Western Hemisphere Travel Initiative at http://www.cbsa-asfc.gc.ca/whti-ivho/edl-pcp-eng.html (April 12, 2011).

7 A similar federal initiative has been geared towards Canada's First Nations communities. Canada obtained approval from United States Customs and Border Protection for the Secure Certificate of Indian Status (SCIS) for use as a cross-border document. The new SCIS is accepted by US Customs when First Nation individuals present it at a land or sea border crossing. See Chiefs of Ontario (2009).

\section{References}

Adler, Emanuel and Michael Barnett. 1998. Security Communities. Cambridge: Cambridge University Press.

Andreas, Peter. 2003. Perspective: Border Security in the Age of Globalization. Boston: Federal Reserve Bank of Boston.

Andreas, Peter. 2005. "The Mexicanization of the US-Canada Border." International Journal 60(2): 449-62.

Andreas, Peter and Thomas J. Biersteker. 2003. The Rebordering of North America: Integration and Exclusion in a New Security Context. New York: Routledge.

Barrera, Jorge. 2009a. "Plan to arm border guards 'act of war,' native chief warns." The Gazette (Montreal). May 29, 2009. http://www.montrealgazette.com/news/ Plan + border+ guards + chief/1644252/story.html (September 22, 2009).

Barrera, Jorge. 2009b. "US senators enter Akwesasne border-closure." Canwest News Service. June 16, 2009. http://www.canada.com/story_print.html?id=1686769\&sponsor=. (September 28, 2009).

Bow, Brian. 2009. The Politics of Linkage: Power, Interdependence, and Ideas in Canada-US Relations. Vancouver: UBC Press.

Bowman, Karlyn. 2005. "US Public Opinion and the Terrorist Threat." In Threat Perceptions in the United States and Canada: Assessing the Public's Attitudes toward Security and Risk in North America. Washington: Woodrow Wilson International Center for Scholars.

Bradbury, Susan L. and Daniel E. Turbeville, III. 2008. "Are Enhanced Trade and Enhanced Security Mutually Exclusive? The Western Canada-US Borderland in a Post-9/ 11World." The American Review of Canadian Studies 38(3): 317-40. 
Bukowczyk, John J., Nora Faires, David R. Smith and Randy William Widdis. 2005. Permeable Border: The Great Lakes Basin as a Transnational Region, 1650-1990. Pittsburgh: University of Pittsburg Press.

Canadian Border Security Agency. 2009. "Fact Sheet: The Canada Border Services Agency's Arming Initiative.” September 3, 2009. http://www.cbsa-asfc.gc.ca/media/facts-faits/ 063-eng.html (April 12, 2011).

Canadian Border Services Agency. 2011. Western Hemisphere Travel Initiative. http:// www.cbsa-asfc.gc.ca/whti-ivho/menu-eng.html (April 12, 2011).

CBC News. 2006. "Walk-away policy remains until border guards armed." September 1, 2006. http://www.cbc.ca/canada/story/2006/09/01/borderguards-union.html (April 12, 2011).

CBC News. 2008. "PM voices concerns about 'thickening' of U.S. border." April 22, 2008. http://www.cbc.ca/news/world/story/2008/04/22/three-amigos.html. (April 12, 2011).

CBC News. 2009a. "Cornwall businesses hurt by border post move." August 25, 2009. http://license.icopyright.net/user/viewFreeUse.act?fuid=NTEyMTUyOA\%3D\%3D. (September 30, 2009).

CBC News. 2009b. "Interview with US Homeland Security Secretary Janet Napolitano." April 20, 2009. http://www.cbc.ca/news/canada/story/2009/04/20/f-transcriptnapolitano-macdonald-interview.html. (April 12, 2011).

Chiefs of Ontario. 2009. "Regional Chief for Ontario supports citizens and leadership of Akwesasne in their opposition to arming of border guards." June 1, 2009. http:// chiefs-of-ontario.org/News/Default.aspx?NewsID $=84$ (April 12, 2011).

Clarkson, Stephen. 2001. "The Multi-Level State: Canada in the Semi-Periphery of both Continentalism and Globalization." Review of International Political Economy 8(3): 501-527.

Clarkson, Stephen. 2008. Does North America Exist? Governing the Continent After NAFTA and 9/11. Toronto, O.N.: University of Toronto Press.

De Souza, Mike. 2010. "Cross-border security plan made with U.S." The Gazette (Montreal). July 14, 2010. http://www.montrealgazette.com/news/cross + border+ security + plan + made + with/3274390/story.html (July 19, 2010).

Dobson, Wendy. 2002. "Shaping the Future of the North American Economic Space: A Framework for Action." C. D. Howe Institute Commentary: The Border Papers 162: $1-32$.

Donnely, Thomas and Vance Serchuk. 2005. "Transforming America's Alliances.” National Security Outlook January: 1-7.

Dougherty, Kevin. 2009. "Few takers for new Quebec border card: Slow start; Just 11,000 pay for 'enhanced' driver's permit." The Gazette (Montreal). May 27, 2009 http:// www.canada.com/news/takers + quebec + border + card/1635072/story.html (August 25, 2009).

Foreign Affairs and International Trade Canada. 2001. The Canada-U.S. Smart Border Declaration. December 12, 2001. http://www.international.gc.ca/anti-terrorism/ declaration-en.asp (April 12, 2011).

Gattinger, Monica and Geoffrey Hale, eds. 2010. Borders and Bridges: Canada's Policy Relations in North America. Oxford: Oxford University Press.

Gilpin, Robert 1987. The Political Economy of International Relations. Princeton NJ: Princeton University Press.

Globerman, Steven and Paul Storer. 2008. The Impacts of 9/11 on Canada-US Trade. Toronto: University of Toronto Press.

Globerman, Steven and Paul Storer. 2009. "Border Security and Canadian Exports to the United States: Evidence and Policy Implications." Canadian Public Policy 35(2): 171-86.

Goldfarb, Danielle. 2003. "The Road to a Canada-US Customs Union: Step-by-Step or in a Single Bound?” C.D. Howe Institute Commentary 184: 1-30. 
Golob, Stephanie R. 2008. "The Return of the Quiet Canadian: Canada's Approach to Regional Integration after 9/11.” In An Independent Foreign Policy for Canada? Challenges and Choices for the Future, ed. Brian Bow and Patrick Lennox. Toronto: University of Toronto Press.

Gonzalez, Guadalupe and Stephen Haggard. 1998. "The United States and Mexico: A Pluralistic Security Community?” In Security Communities, ed. Emanuel Adler and Michael Barnett. Cambridge: Cambridge University Press.

Gotlieb, Allan. 2004. "Romanticism and Realism in Canada's Foreign Policy." Benefactors Lecture. Toronto: C.D. Howe Institute.

Grieco, Joseph M. 1990. Cooperation among Nations: Europe, America, and Non-Tariff Barriers to Trade. Ithaca, New York: Cornell University Press.

Haacke, Jurgen and Paul D. Williams. 2008. "Regional Arrangements, Securitization, and Transnational Security Challenges: The African Union and the Association of Southeast Asian Nations Compared." Security Studies 17: 775-809.

Haglund, David G. 2010. "A Security Community_-'If You Can Keep It': Societal Security, Demography, and the North American Zone of Peace." In Canada's Foreign and Security Policy Soft and Hard Strategies of a Middle Power, ed. Nik Hynek and David Bosold. Oxford: Oxford University Press.

Harper, Stephen. 2007. "Prime Minister Harper signals Canada's renewed engagement in the Americas." July 17, 2007. http://pm.gc.ca/eng/media.asp?id=1760 (April 12, 2011).

Harvey, Frank P. 2007. "The Homeland Security Dilemma: Imagination, Failure and the Escalating Costs of Perfecting Security." Canadian Journal of Political Science 40(2): 283-316.

Healy, Teresa and Sheila Katz. 2008. "Big and Little Brother Bilateralism: Security, Prosperity, and Canada's Deal with Colombia." Studies in Political Economy 82: 35-60.

Hirschman, Albert O. 1970. Exit, Voice, and Loyalty: Responses to Decline in Firms, Organizations and States. Cambridge: Harvard University Press.

Jachtenfuchs, Markus and Beate Kohler-Koch. 2004. "Multi-Level Governance." In European Integration Theory, ed. Antje Wiener and Thomas Diez. Oxford: Oxford University Press.

Katada, Saori N. 1997. "Two Aid Hegemons: Japanese-US Interaction and Aid Allocation to Latin America and the Caribbean." World Development 25(6): 931-45.

Keohane, Robert and Joseph N. Nye. 2001. Power and Interdependence. New York: Longman.

Kukucha, Christopher J. 2008. The Provinces and Canadian Foreign Trade Policy. Vancouver: UBC Press.

Lennox, Patrick. 2007. "From Golden Straightjacket to Kevlar Vest: Canada's Transformation to a Security State." Canadian Journal of Political Science 40(4): 1017-38.

Lennox, Patrick. 2009. At Home and Abroad: The Canada-US Relationship and Canada's Place in the World. Vancouver: UBC Press.

MacLeod, Ian. 2009. "US to beef up border patrol by Canada." The Ottawa Citizen. June 11, 2009. http://canada.com/story_print.html?id=1686900\&sponsor $=($ September 28 , 2009).

MacPherson, Alan D. and James E. McConnell. 2007. "A Survey of Cross-Border Trade at a Time of Heightened Security: The Case of Niagara Bi-National Region." American Review of Canadian Studies 37(3): 301-321.

MacPherson, Alan D., J.E. McConnell, A. Vance and V. Vanchan. 2006. "The Impact of US Government Antiterrorism Policies on Canada-US Cross-Border Commerce." Professional Geographer 58: 266-77.

Marks, Gary, Liesbet Hooghe and Kermit Blank. 1996. "European Integration from the 1980s: State-Centric v. Multi-level Governance." Journal of Common Market Studies 34(3): 341-78. 
Mason, Dwight N. 2005. "The Canadian-American North American Defence Alliance in 2005." International Journal 60(2): 385-396.

Mayeda, Andrew. 2009. "Homeland Security chief says Canada-US border review "misconstrued.'” The National Post. February 27, 2009. http://www.nationalpost.com/ most-popular/story.html?id=1336757 (April 12, 2011).

McRoberts, Kenneth. 2001. "Canada and the Multinational State." Canadian Journal of Political Science 34(4): 683-713.

Meyers, Deborah Waller. 2003. "Does 'Smarter' Lead to Safer? An Assessment of the US Border Accords with Canada and Mexico." International Migration 41(4): 5-44.

Miller, Benjamin. 1998. "The Logic of US Military Interventions in the Post-Cold War Era." Contemporary Security Policy 19(3): 72-109.

Ministère des Relations internationales. 2006a. Contribuer à l'édification d'un monde plus sûr ou le défi de la sécurité pour le Québec. Québec QC : Gouvernement du Québec.

Ministère des Relations internationales. 2006b. La politique internationale du Québec: La force de l'action concertée. Québec, Q.C.: Gouvernement du Québec.

Ministère des Relations internationales. 2008. "Québec: A Major Partner for North American Security.” Québec's International Initiatives 3, October : 1-4.

Ministère des Relations internationales. 2009. La politique internationale du Québec: Plan d'action 2009-2014. Québec QC: Gouvernement du Québec.

Ministère des Relations internationales. 2010. Stratégie du gouvernement du Québec à l'égard des Etats-Unis. Québec QC: Gouvernement du Québec.

Napolitano, Janet. 2009. "The United States and Canada: Toward a Better Border." Conference organized by the Metropolitan Policy Program of the Brookings Institute and the International Council of Canada. Washington DC.

Olson, Mancur. 1971. The Logic of Collective Action: Public Goods and the Theory of Groups. Cambridge: Harvard University Press.

Owen, John. 2001/2002. "Transnational Liberalism and US Primacy." International Security 26(3): 117-53.

Paquin, Stéphane, ed. 2006. Les relations internationals du Québec depuis la Doctrine Gérin-Lajoie (1965-2005). Québec : Les Presses de l'Universite Laval.

Pastor, Robert A. 2008. "The Future of North America." Foreign Affairs 87(4): 84-98.

Posen, Barry R. 2006. "European Union Security and Defense Policy: Response to Unipolarity?" Security Studies 15(2): 149-86.

Public Safety Canada. 2008. Smart Border Declaration and Action Plan. May 3, 2008. http://www.publicsafety.gc.ca/prg/le/bs/sbdap-eng.aspx (April 12, 2011).

Public Safety Canada. 2009. Government Operations Centre. May 6, 2009. http:// www.publicsafety.gc.ca/prg/em/goc/index-eng.aspx (April 12, 2011).

Sakurada, Daizo. 1998. "Why We Need the US-Japan Security Treaty." Asia Pacific Review 5(1): $13-38$.

Sandler, Todd. 1993. "The Economic Theory of Alliances: A Survey." Journal of Conflict Resolution 37(3): 446-83.

Sands, Christopher. 2008. "An Independent Security Policy for Canada in the Age of Sacred Terror?" In An Independent Foreign Policy for Canada? Challenges and Choices for the Future, ed. Brian Bow and Patrick Lennox. Toronto: University of Toronto Press.

Sands, Christopher. 2009. Toward a New Frontier: Improving the US-Canadian Border. Washington, DC: The Brookings Institute.

Savage, Luiza Ch. 2009. "DHS Secretary Napolitano on the Northern Border." Macleans, February 27, 2009. http://www2.macleans.ca/2009/02/27/dhs-secretary-napolitanoon-the-northern-border/ (September 30, 2009).

Security and Prosperity Partnership of North America (SPP). 2009. "SPP Myths and Facts." SPP.Gov http://www.spp.gov/myths_vs_facts.asp (September 28, 2009). 
SES and the University at Buffalo. 2007. Americans Keen on Security and Border Co-operation with Canada, Canada-US Border \& Security Tracking Study. http:// www.sesresearch.com/library/polls/POLNAT-W07-T222.pdf (April 12, 2011).

Snidal, Duncan. 1991. "Relative Gains and the Pattern of International Cooperation." American Political Science Review 85: 710-26.

Sokolsky, Joel J. and Philippe Lagassé. 2006. "Suspenders and a Belt: Perimeter and Border Security in Canada-US Relations." Canadian Foreign Policy 12(3): 15-29.

Statistics Canada. 2011a. Table 228-0003-Merchandise imports and exports, by major groups and principal trading areas for the United States, including Puerto Rico, annual (dollars). CANSIM (database), Using E-STAT (distributor). http://estat.statcan.gc.ca/ cgi-win/cnsmcgi.exe?Lang =E\&EST-Fi=EStat/English/CII_1-eng.htm. (March 23, 2011).

Statistics Canada. 2011b. Table 387-0004-International travellers, quarterly (persons). CANSIM, Using E-STAT. http://estat.statcan.gc.ca/cgi-win/cnsmcgi.exe?Lang= E\&ESTFi $=$ EStat/English/CII_1-eng.htm. (March 23, 2011).

Thacher, David. 2005. "The Local Role in Homeland Security." Law \& Society Review 39(3): 635-676.

Transport Canada. 2009. Land Border Crossing Investments Map. Ottawa, ON: Government of Canada. http://www.tc.gc.ca/policy/acg/acgd/map/border-map.html (August $25,2009)$.

US Department of Transportation. 2011. Research and Innovative Technology Administration, Bureau of Transportation Statistics. http://www.bts.gov/programs/ international/transborder/TBDR_BC/TBDR_BCQ.html. (March 23, 2011).

Walt, Stephen M. 1997. "Why Alliances Endure or Collapse." Survival 39(1): 156-79.

Waltz, Kenneth. 1979. Theory of International Politics. Reading MA: Addison-Wesley.

Zartman, I. William. 1997. "The Structuralist Dilemma in Negotiation" (working paper 1). Research Group in International Security (REGIS). Université de Montréal and McGill University.

Zartman, I. William and Jeffrey Z. Rubin, eds. 2002. Power and Negotiation. Ann Arbor, MI: University of Michigan Press. 